ELORE (ISSN 1456-3010), vol. $18-1 / 2011$.

Julkaisija: Suomen Kansantietouden Tutkijain Seura ry.

[http://www.elore.fi/arkisto/1_11/kirjat_makkonen.pdf]

KIRJA-ARVIO

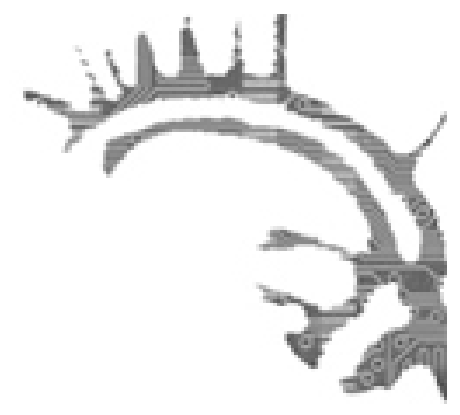

\title{
RADIKAALIEN, POPPARIEN JA KIRJAILIJOIDEN TULKINTOJA KUUSIKYMMENTÄLUVUSTA
}

MIETTUNEN, KATJA-MARIA 2009: Menneisyys ja historiakuva. Suomalainen kuusikymmentäluku muistelijoiden rakentamana ajanjaksona. Bibliotheca Historica 126. Helsinki: SKS. 306 sivua.

\section{Elina Makkonen}

Katja-Maria Miettusen historian alan väitöskirjassa tarkastellaan historiakuvan rakentumista ja merkitystä sekä kuusikymmentälukua kolmen muistelijaryhmän, radikaalien, poppareiden ja kirjailijoiden, rakentamana ajanjaksona. Tutkimuksen kohteena on se, miten ja millainen historiakuva kuusikymmenluvusta julkisissa muisteluissa rakentuu, ja mikä on historiakuvan suhde menneisyyteen.

Miettusen mukaan historiakuvat ovat merkittäviä, koska ne muokkaavat ihmisten käsityksiä menneisyydestä ja sen merkityksestä. Miettunen määrittelee historiakuvan kokonaiskäsitykseksi siitä, millainen jokin menneisyyteen sijoittuva asia oli ja mikä on tuon asian merkitys nykyisyydessä. Historiakuva on "menneisyydestä tehtyjen kertomusten valikoitujen piirteiden avulla luotu kuva menneisyydestä ja sen merkityksellisyydestä” (s. 11).

\section{MUISTELEVAT RYHMÄT JA KÄYTETYT AINEISTOT}

Historiakuvat eivät muotoudu sattumalta, vaan niiden taustalla on aktiivisia toimijoita, joilla on omat motiivinsa. Miettusen tutkimuksessa näitä toimijoita ovat radikaalit, popparit ja kirjailijat. Heidän muistelmiensa käyttämistä perustellaan sillä, että juuri he ovat pyrkineet rakentamaan kuusikymmentäluvun historiakuvaa aktiivisesti ja tarkoituksellisesti samoin kuin muokkaamaan käsityksiä tuon vuosikymmenen olemuksesta. Niin radikaalit, popparit kuin kirjailijatkin ovat olleet median vakiohaastateltavia silloin, kun on käsitelty kuusikymmentälukua.

Radikaaleiksi nimetyn ryhmän jäsenet ovat radikaaliin liikehditään osallistuneita 
Elina Makkonen: Radikaalien, popparien ja kirjailijoiden tulkintoja kuusikymmentäluvusta

henkilöitä, joiden keskeinen muistelun piirre ja aihe on radikalismi. He ovat muistelleet kuusikymmentälukua 1970-luvulta lähtien, mutta 1980-luvun puolivälistä 1990-luvun puoliväliin muisteleminen oli erityisen vilkasta. Toki tämänkin jälkeen radikaalit ovat muistelleet heille tärkeää vuosikymmentä. Siinä vaiheessa, kun radikaalien muistelutoiminta väheni, muut ryhmät alkoivat tuottaa omaa tulkintaansa kuusikymmenluvusta. Näistä tärkeimpänä ryhmänä Miettunen pitää 1960-luvun popmuusikoita ja heidän lähipiirissään vaikuttaneita henkilöitä, joita tutkimuksessa kutsutaan poppareiksi. Viimeisten vuosien aikana on ilmestynyt runsaasti poppareiden muistelmia, ja siten nämä ovat olleet usein esillä myös mediassa. Miettunen kuitenkin toteaa, että siinä missä radikaalien tarina kuusikymmentäluvusta on yhtenäinen ja koko yhteiskunnan läpäisevä, on poppareiden tarina hajanaisempi ja epäyhtenäisempi.

Kirjailijat on otettu mukaan tutkimukseen, koska heidän muistelunsa tuottavat erilaista näkökulmaa. Tutkija on sitä mieltä, että kirjailijoiden muisteluilla on painoarvoa historiakuvan rakentamisessa, koska kirjailijoiden oletetaan näkevän asioita tarkemmin ja heidän tekstejään myös luetaan ahkerasti. Itse asiassa kyse ei ole selkeästä ja yhtenäisestä ryhmästä, vaan joukosta kuusikymmentäluvulla toimineita kirjailijoita ja kustannusyhtiöissä työskennelleitä henkilöitä. Heidän muisteluissaan korostuu yksilöllisyys, kun taas radikaaleja ja poppareita sitoo ryhmäksi tapa muistella kuusikymmentälukua ryhmän näkökulmasta. Kirjailijat vastaavasti toimivat muistelmissaan kirjailijanroolinsa puitteissa menneisyyden intellektuelleina analysoijina.

Tutkimuksessa käytetyt muistelut ovat julkaistuja muistelmia ja muita muisteluluonteisia tekstejä, esimerkiksi lehtiartikkeleita sekä tiedotusvälineille ja teoksiin annettuja haastatteluja. Miettunen ei ole itse haastatellut tutkittaviaan, vaan käyttänyt nimenomaan julkisuutta varten tehtyjä haastatteluja. Lähdemateriaalina on käytetty myös sellaista 1960-lukua käsittelevää kaunokirjallisuutta, jonka tutkija olettaa olevan ainakin osin omaelämäkerrallista. Vanhimmat muistelut ovat 1970-luvulta ja uusimmat vuodelta 2008. Muistelijoita on noin 140.

Olisin toivonut tutkijan kertovan vielä tarkemmin, miksi hän on valinnut juuri nämä muistelukset. Myös erilaisten aineistojen erilaista luonnetta olisi voinut pohtia. Ennen kaikkea minua jäi kiinnostamaan se, miten muistelmien julkinen luonne on vaikuttanut tutkimuksessa muodostuvaan tulkintaan kuusikymmentäluvusta. Mitä kerrotaan ja mitä jätetään kertomatta siksi, että tiedetään muisteluiden olevan julkisia? Entä kenelle muistelija tv-haastattelussa puhuu tai kenelle muistelmissaan kirjoittaa?

\section{TARINA KUUSIKYMMENTÄLUVUSTA}

Tutkimuksessa ei siis tarkastella 1960-lukua vaan kuusikymmentäluvun historikuvaa. Miettunen tekee käsitteellisen erottelun termien 1960-luku ja kuusikymmentäluku välille. 1960-luku on hänen tutkimuksessaan kronologinen ajanjakso, joka kattaa vuodet 1960-1969. Sen sijaan kuusikymmentäluku tarkoittaa historiakuvan kuusikymmentälukua, jolloin se on henkinen aikakausi ja eräänlainen mielenmaisema. Kuusikymmentäluku ei myöskään ole tiukasti sidoksissa vuosiin, ja se voi eri ihmisillä alkaa ja päättyä eri aikoina. 
Elina Makkonen: Radikaalien, popparien ja kirjailijoiden tulkintoja kuusikymmentäluvusta

Tutkimus rakentuu viidestä luvusta, joissa ensimmäinen "Historiakuva ja menneisyyden muistellut merkitykset" toimii tutkimuksen johdantona. Sitä seuraa erittäin laaja, yli 160-sivuinen luku "Suomalainen kuusikymmentäluku muistelijoiden kertomana tarinana", jossa eri ryhmien muisteluksia temaattisesti tarkastelemalla pilkotaan historiakuvaa palasiksi ja kirjoitetaan tarina tarkalteltavasta vuosikymmenestä. Miettunen perustelee ratkaisuaan sillä, että koska historiakuva on kokonaisuus, sen rakentumisen keskeisenä tutkimusmenetelmänä on kuvan purkaminen.

Tarina jakautuu viiteen elementtiin ja samalla alalukuun, joissa kerrotaan, miksi kuusikymmentäluku alkoi, miten se ilmeni, mitkä olivat sen merkittävät hetket, mihin se päättyi ja mikä oli sen merkitys. Radikaalien tarinassa kaikki elementit tulevat esille, kun taas poppareiden tarinassa korostuvat kuusikymmentäluvun ilmiöt. Kuusikymmentäluvun tapahtumista ja hetkistä kuvataan Lapualaisoopperaa, Vanhan valtausta, Tsekkoslovakian miehitystä ja shaahin vastaisia mielenosoituksia. Ilmiöistä taas tulevat esille muun muassa rauhanliike, kolmasmaalaisuus, uusvasemmistolaisuus, kansainvälistyminen, kulttuurin radikalisoituminen ja popkulttuuri.

Muistelijoiden kertoma tarina on historiakuvan runko, joka vertautuu tutkimuksen seuraavassa luvussa historiakuvan marginaaliin jääneisiin ilmiöihin ja ryhmiin (hipit, anarkistit, underground ja maolaisuus). Näitä on tarkasteltu siksi, että ne paljastavat historiakuvan rakentamisen mekanismit ja muistelemalla tapahtuvan historiakuvan rakentumisen rajat. Marginaalisia ilmiöitä tarkasteleva luku liittyykin olennaisesti edelliseen lukuun toimien sen vastatarinana, kun taas seuraava, kuusikymmentäluvun merkityksellistymistä tarkasteleva luku yhdistää aiemmissa kahdessa luvussa esitettyjen muistelijoiden kertomukset kuvaukseksi "kuusikymmentäluvun syvemmästä olemuksesta" (s. 241). Siinä tarkastellaan esimerkiksi kysymyksiä nostalgiasta sekä toiseuden ja meisyyden rakentumisesta. Tässä tarkastelussa muistelijaryhmien erot osittain katoavat ja kuusikymmentäluku nivoutuu osaksi nykyisyyttä. Tämä tutkimuksen neljäs luku toimiikin tavallaan tutkimuksen yhteenvetona, jota täydentää viimeinen luku, jossa pohditaan identiteetin ja kollektiivisen muistin kautta historiakuvan ulottuvuuksia.

Luultavasti tutkija on miettinyt rakennetta tarkkaan, mutta itse en pidä rakennetta tasapainoisena. Kirjan laajin luku nimittäin kattaa yli puolet tutkimuksesta, kun taas muut luvut ovat selvästi lyhyempiä. Toisen luvun laajuutta voi kyllä perustella sillä, että siinä on muodostettu tarina kuusikymmentäluvusta, eikä sitä ilmeisesti ole haluttu lähteä rikkomaan useampaan lukuun. Toinen luku kuitenkin jakautuu vielä viiteen alalukuun, joista laajin on sekin lähes 100-sivuinen. Kirjan lukuja ei ole numeroitu ja etenkin laajimman luvun kohdalla tämä häiritsi rakenteen hahmottamista. Luvussa oli käytetty paljon eritasoisia otsikoita, ja välillä oli sisällysluetteloa katsomatta vaikea tietää, mikä alaluku tai kappale kuului minkin laajemman luvun alle.

\section{HistoriaKUVAN TUTKIMISEN HAASTEITA}

Miettusen tutkimuksesta nousee esille paljon kiinnostavia kysymyksiä menneisyyden merkityksestä niin yksilöille kuin yhteisöillekin. Se myös kuvaa mielenkiintoisesti yhtä lähihistoriamme merkittävää ajanjaksoa ja siitä tuotettuja erilaisia tulkintoja. Eri muistelijaryhmien ja yksilöiden muistikuvia kuusikymmentäluvusta keskustelutetaan 
hyvin. Samoin historiakuvan rakentumista ja eri toimijoiden vaikutusta historiakuvaan puretaan ansiokkaasti ja kiinnostavasti.

Olisin toivonut tutkijan sekä määrittelevän että käsittelevän tarkemmin eri aloilla käytyjen keskusteluiden kautta identiteettien rakentumista, kollektiivista muistia, nostalgiaa sekä meisyyden ja toiseuden rakentumista. Valitettavasti Miettunen ei tältä osin kytke omia tulkintojaan riittävän vahvasti ja vankasti tutkimuskirjallisuuteen, ja myös yllä mainittujen käsitteiden määrittely on jäänyt puolitiehen.

Tutkija ei myöskään ole huomioinut omaa rooliaan, sillä valitsemalla tietyt muistelijaryhmät ja näiden muistelukset tutkimuksensa kohteeksi, hän on itse ollut konstruoimassa tietynlaista tarinaa kuusikymmentäluvusta. Toki tutkimuksen pääasiallisena kohteena ovat juuri näiden kolmen ryhmän tuottamat historiakuvat ja tämän historiakuvan merkitys, mutta siitä huolimatta olisin toivonut tutkijan pohtivan edes jonkin verran myös refleksiivisiä kysymyksiä.

Selvittäessään suomalaisen kuusikymmentäluvun historiakuvan luonnetta kolmen muistelijaryhmän kautta Miettunen tekee päätelmiä historiakuvan rakentumisesta yleensä. Hänen mukaansa historiakuvaa rakennetaan erilaisilla foorumeilla, ja rakentamiseen osallistuvat aikalaisten lisäksi myös historiantutkijat, mutta myös esimerkiksi elokuvat ja romaanit. Miettunen korostaa, ettei muisteluksissa pelkästään kerrota kuusikymmentäluvun tapahtumista tai ilmiöistä tai tuoteta tietynlaista tarinaa, vaan luodaan vuosikymmen sellaisena kuin se muistetaan ja halutaan muistaa. Samoin hän painottaa, ettei merkittävää ei ole vain se, mitä on tapahtunut vaan yhtä lailla se, mitä uskotaan tapahtuneen. Samoin tapahtumille annetut merkitykset eivätkä niinkään tapahtumat ovat merkittäviä. Tutkija tähdentää myös sitä, että menneisyyden merkitys toteutuu nimenomaan vuorovaikutuksessa nykyisyyden kanssa, jolloin sillä on myös kytköksiä tulevaisuuteen.

Kuusikymmentälukua muistelleet vetoavat omiin kokemuksiinsa legitimoidessaan rooliaan historiakuvan rakentajina. Muistelijat ovat sitä mieltä, että he ovat oikeita henkilöitä kertomaan kuusikymmentäluvusta, koska juuri he ovat kokeneet tuon vuosikymmenen oikealla tavalla. Lisäksi he näyttävät kokevan, että heillä on oikeus, mutta myös velvollisuus kertoa omista kokemuksistaan ja muistoistaan. Miettunen toteaa, että muistelijoiden tavoitteena on tehdä omasta menneisyystulkinnastaan myös historiankirjoitusta. Muisteluissa onkin nähtävissä pyrkimys tehdä kuusikymmentäluvusta osa muidenkin kuin aikalaisten identiteettiä, jolloin siitä pyritään tekemään merkittävä niillekin, joilla ei ollut mitään tekemistä sen kanssa.

Vaikka tutkimuksen tarkoituksena ei ole kirjoittaa 1960-luvun historiaa, niin itselleni teos oli myös tietopaketti tuon vuosikymmenen tapahtumista ja ilmiöistä. Mutta, kuten tutkimuksen tekijä huomauttaa useaan otteeseen, on lukijan hyvä muistaa, että kyse on valikoidusta ja tuotetusta historiakuvasta, jossa jotkin tuon vuosikymmenen ilmiöt ja tapahtumat on jätetty käsittelemättä. Muistelijoilla on kuitenkin oikeus muistella menneisyyttään tietystä näkökulmasta, kun taas muiden on hyvä muistaa, että muistelijoiden rakentama historiakuva kuitenkin on vain yksi tapa kuvata menneisyyttä.

Filosofian tohtori Elina Makkonen on kontiolahtelainen perinteentutkija. 